九州大学学術情報リポジトリ

Kyushu University Institutional Repository

\title{
Land Use Effectiveness by Farm Households after Land and Forest Allocation at Tran Yen District, Yen Bai Province
}

Nguyen Thenh Tra

Faculty of Land Resoruces and Environment, Hanoi Agricultural University

Egashira, Kazuhiko

Laboratory of Soil Science, Division of Soil Science and Plant Production, Depaertment of Plant Resoruces, Faculty of Agriculture, Kyushu University

https://doi.org/10.5109/4607

出版情報: 九州大学大学院農学研究院紀要. 49 (2)，pp.461-466，2004-10-01. Faculty of Agriculture, Kyushu University

バージョン：

権利関係 : 


\title{
Land Use Effectiveness by Farm Households after Land and Forest Allocation at Tran Yen District, Yen Bai Province
}

\author{
NGUYEN Thanh Tra ${ }^{1}$ and Kazuhiko EGASHIRA* \\ Laboratory of Soil Science, Division of Soil Science and Plant Production, \\ Department of Plant Resources, Faculty of Agriculture, \\ Kyushu University, Fukuoka 812-8581, Japan \\ (Received June 30, 2004 and accepted July 13, 2004)
}

\begin{abstract}
Viet Nam underwent dramatic changes due to policy reform in the 1980s. One of the great achievements in the agricultural sector is land allocation to farm households. To confirm it, study on the evaluation of the land use effectiveness by farm households after land and forest allocation was carried out in Tran Yen district, Yen Bai province, which is rich in human resources, and has different land resources of paddy field to hilly and mountainous land and climatic conditions suitable to development of agriculture and forestry. The study was carried out through collection of related documents and interview to the selected $150 \mathrm{farm}$ households from 3 communes of Bao Dap, Minh Quan and Au Lau. The farm households were found to be contented with the land and forest allocation. It encouraged them to change methods of production and to decrease disputes on the land use right and improper use of land. Structure of land use was changed to increase the agricultural and forestry land area rapidly, to raise crop yield and to develop forest production. The land use effectiveness was evaluated to be increased significantly after land and forest allocation.
\end{abstract}

\section{INTRODUCTION}

In Viet Nam, "Doi Moi" was started in 1986 as a policy of the Communist Party. The central planned economy was transformed into the market-oriented economy under keeping socialism. In the agricultural sector the strategy was framed as follows after "Doi Moi" was issued: 1) establishing sustainable agriculture by region; 2) upgrading rural economy; and 3) stabilizing political system in the rural area. (Nguyen et al., 2002). Agricultural policies consisting of price policy, land policy, rural credit policy, and rural investment policy have been issued to develop the strategy framework and contributed to the agricultural and rural improvements. Concerning the land policy, the Communist Party approved Resolution No. 10 in 1988. It was one of the epochs in terms of permitting farmers private use right of the allocated land. Land Law was issued in 1993 and became a next step to expand the land use right of farmers.

Agricultural and forestry land allocation to organizations, households and individuals in upland areas according to the overall planning has been a broad policy of the Vietnam Communist Party and the Government since issue of Land Law in 1993. Ordinances Nos. 64/N\&-CP, 02/N\&-CP, 85/1999/N\&-CP and 163/1999/N\&-CP issued for proper allocation

\footnotetext{
1 Faculty of Land Resources and Environment, Hanoi Agricultural University, Gia Lam, Ha Noi, Viet Nam

* Corresponding author (E-mail: kegashi@agr.kyushu-u.ac.jp)
} 
of agricultural and forestry land to households, permitted the agricultural land use of the duration of 20 years for the hilly and mountainous land, of 50 years for the miscellaneous garden land and long-time tree planting land, and of 50 years for the forestry land. The residential land was allocated in the longer-term period. It was a policy to fasten labour with land and to give an incentive for agricultural and forestry production for the gradual socio-economic stabilization and development. Land allocation has created a firm legitimate basis for the land use right of people. In order to observe and evaluate opportunely the effects of the land allocation policy on land management and land use effectiveness in the hilly and mountainous region, study on the evaluation of the land use effectiveness by farm households after land and forest allocation was carried out.

\section{LOCATION}

\section{Study area}

Study on the land use effectiveness by farm households after allocation of agricultural and forestry land was carried out in Bao Dap, Minh Quan and Au Lau communes of Tran Yen district, Yen Bai province, located in the Northern Mountainous region. The allowable land area of the 3 communes was $3,604.21$ ha. The area of the land allocated to farm households was 2,998.64 ha in total, of which agricultural land was 1,402.10 ha, forestry land was $1,511.22$ ha and residential land was 85.32 ha. Up to 2002, land allocation to farm households was completed in all communes of the district. Therefore, agriculture and forestry in the district have been highly developed, and the living standard of farm households has been raised to a higher extent.

\section{Natural and socio-economic conditions of Tran Yen district}

Tran Yen district has the total natural land area of $69,074.09$ ha, including 1 township and 28 communes, of which agricultural land is $9,992.25 \mathrm{ha}$, forest is $41,000.61$ ha, land for specialized use is $2,219.83 \mathrm{ha}$, the residential area is $459.40 \mathrm{ha}$, and the abandoned area is $15,402.00$ ha. The center of the district is $13.5 \mathrm{~km}$ distant from Yen Bai city. The district is divided into 2 zones: the plain zone comprising 12 communes along the Red River and the upland zone creating the concentrated spring-stream systems flowing into the Red River basin. Tran Yen district is 96,437 in population and is rich in human resources, having large labour force of 49,981 people. The majority of people are Kinh, with Tay, Dzao, Muong and H'mong as minorities. The labouring people make up $51.83 \%$ of the total population and mainly work in agriculture and forestry. But, the educational standard and technical skill of people in Tran Yen district are still limited.

\section{METHODS}

\section{Collection and survey of data}

Legal documents and documents relating to the land allocation policy since issue of Land Law in 1993 in Bao Dap, Minh Quan and Au Lau communes of Tran Yen district were collected. They are reports, maps relating to the land and forest allocation, and the situation of local land use. Some data on agricultural and forestry activities were also obtained. Distribution of agricultural and forestry land at the studied communes, in 
addition to opinions of farm households on the land use effectiveness, were surveyed through interview to farm households by using a set of questionnaires. In this context, 150 farm households, 50 from each commune, were selected for interview.

\section{Data treatment}

Microstation software was applied to make the map of investigated farm households. Excel software was used to analyze opinions of farm households on the land use effectiveness after being allocated with land and forest.

\section{RESULTS AND DISCUSSION}

\section{Allocation of land to farm households}

Allocation of land to the 150 farm households selected for interview in the 3 communes is shown in Table 1 . The allocated land area was 202.65 ha in total. Among the allocated land, agricultural and forestry land occupied $40.4 \%$ and $57.4 \%$, respectively, leaving $2.2 \%$ to residential land. The total allocated land area was in the increasing order of Bao Dap, Au Lau, and Minh Quan communes. In Au Lau commune the proportion of agricultural and forestry land was nearly equal. The agricultural land area was over the forestry land area in Bao Dap commune, whereas the latter exceeded the former in Minh Quan commune.

Table 1. Allocation of land to farm households.

\begin{tabular}{lrrrrr}
\hline \multirow{2}{*}{ Contents } & \multicolumn{2}{c}{ Total } & \multicolumn{3}{c}{ Commune } \\
\cline { 2 - 6 } & Total & $\begin{array}{c}\text { Rate } \\
\text { (\%) }\end{array}$ & $\begin{array}{l}\text { Bao } \\
\text { Dap }\end{array}$ & $\begin{array}{l}\text { Minh } \\
\text { Quan }\end{array}$ & $\begin{array}{c}\text { Au } \\
\text { Lau }\end{array}$ \\
\hline Number of households interviewed & 150 & \multicolumn{1}{c}{ 150 } & 50 & 50 & \multicolumn{1}{l}{50} \\
Allocated total land (ha) & 202.65 & 100 & 45.94 & 82.89 & 73.82 \\
Agricultural land (ha) & 81.81 & 40.4 & 30.08 & 14.69 & 37.04 \\
Forestry land (ha) & 116.34 & 57.4 & 14.52 & 67.01 & 34.81 \\
Residential land (ha) & 4.50 & 2.2 & 1.34 & 1.19 & 1.97 \\
\hline
\end{tabular}

\section{Impacts of land allocation on the land use and crop production}

After land and forest allocation, agricultural and forestry land in 3 communes of Bao Dap, Minh Quan and Au Lau increased significantly in 2002 in comparison with 1995. Namely, the agricultural land area increased from $1,273.80$ ha in 1995 to $1,422.44$ ha in 2002 and the forestry land area increased from 1,327.00 ha in 1995 to 2,096.41 ha in 2002. The area planted with sugarcane and fruit-trees was increased. In contrast, the abandoned land area decreased from 1,705.70 ha in 1995 to 918.35 ha in 2002.

Land and forest allocation promoted to develop crop production. Average food per capita p.a. was increased from $229 \mathrm{~kg}$ in 1995 to $338 \mathrm{~kg}$ in 2002 . Rice yield increased from $3.85 \mathrm{ton} / \mathrm{ha}$ in 1995 to $4.58 \mathrm{ton} / \mathrm{ha}$ in 2002 , and yield of maize and cassava increased from $2.36 \mathrm{ton} / \mathrm{ha}$ in 1995 to $3.61 \mathrm{ton} / \mathrm{ha}$ in 2002 . Forest production was developed; $20.4 \%$ of the interviewed households harvested products of bamboo, luong bamboo, bamboo shoot and keo tree from forest. 


\section{Socio-economic aspects of land and forest allocation}

After issue of the land allocation policy, the area of used land has been increased. Accordingly, investment in production materials or equipment, labour force, fertilizers and plant varieties was significantly enhanced (3-5 million dongs per household p.a.), because farm households were entitled to use the land stably in long-term. Input of families in crop production was increased. $94 \%$ of the interviewed households had main labour force within their families; $90 \%$ of the households informed that they could organize and manage better their own family's labour source in the current management practice and allocation level. Number of disputes on the land use right in 1995 was 15 cases but decreased to 5 cases in 2002; number of the households using the land for improper purposes decreased from 24 in 1995 to 9 in 2002. Land and forest allocation was found to have positive impacts on farm households in terms of development, reservation and protection of environment and ecosystem, besides provision of food and products to the society.

Over 7 years since implementation of land and forest allocation, the living standard and income of farming household has increased considerably, because development in agriculture and forestry changed income of them. Total income increased greatly in $62 \%$ of the interviewed households in the 3 communes; income increased but not greatly in $31 \%$; and income did not increase in the remaining $7 \%$. The proportion of the rich households increased from $4.5 \%$ in 1995 to $5.7 \%$ in 2002; the proportion of the households having income at the average level rose from $58.1 \%$ in 1995 to $67.4 \%$ in 2002 ; and the proportion of the poor households decreased from $23.4 \%$ in 1995 to $21.1 \%$ in 2002. Land and forest allocation promoted to improve the living standard of several households, and some families in the 3 communes now have accumulated assets.

\section{Opinions of farm households on the land use effectiveness after land and forest allocation}

The results of the interview to the selected 150 farm households in the 3 communes on the land use effectiveness after agricultural and forestry land allocation are summarized in Table 2. The majority of farm households looked to be very cheerful to land and forest allocation and raised their awareness and sense of the responsibility as an owner of the allocated land. Opinions of the farm households were almost similar to each other between Bao Dap and Au Lau communes, but the households in Minh Quan commune appeared in a little negative attitude to exercise the land use right compared to those in the other 2 communes. It may reflect allocation of forestry land over agricultural land in Minh Quan commune (Table 1).

$100 \%$ of the interviewed households affirmed that the land and forest allocation really helped them to feel assured for working as an owner and to carry out production on the allocated land. $100 \%$ of the households were contented with the land and forest allocation and were aware of the responsibility and the stable and long-term land use right. $93.3 \%$ of the households affirmed that the land and forest allocation created more favourable conditions for them to invest in use of land and protection of forest. But, only $24.7 \%$ of the households used the land allocation certificate as the mortgage to borrow state loans for production. 
Table 2. Opinions of farm households on the land use effectiveness after land allocation.

\begin{tabular}{|c|c|c|c|c|c|}
\hline \multirow[t]{2}{*}{ Contents } & \multicolumn{2}{|c|}{ Total } & \multicolumn{3}{|c|}{ Commune } \\
\hline & Total & $\begin{array}{c}\text { Rate } \\
(\%)\end{array}$ & $\begin{array}{l}\text { Bao } \\
\text { Dap }\end{array}$ & $\begin{array}{l}\text { Minh } \\
\text { Quan }\end{array}$ & $\begin{array}{l}\mathrm{Au} \\
\mathrm{Lau}\end{array}$ \\
\hline \multicolumn{6}{|c|}{ 1. Do you agree with land and forest allocation policy? } \\
\hline Number of households answering "agree" & 150 & 100 & 50 & 50 & 50 \\
\hline Number of households answering "disagree" & 0 & 0 & 0 & 0 & 0 \\
\hline 2. Actual area used & 198.15 & 100 & 44.60 & 81.70 & 71.85 \\
\hline Agriculture & 81.81 & 41.3 & 30.08 & 14.69 & 37.04 \\
\hline Forestry & 116.34 & 58.7 & 14.52 & 67.01 & 34.81 \\
\hline \multicolumn{6}{|l|}{ 3. Be as free as actual owner? } \\
\hline Number of households answering "yes" & 150 & 100 & 50 & 50 & 50 \\
\hline Number of households answering "no" & 0 & 0 & 0 & 0 & 0 \\
\hline \multicolumn{6}{|l|}{ 4. Is cultivation favorable after allocation? } \\
\hline Number of households answering "favorable" & 150 & 100 & 50 & 50 & 50 \\
\hline Number of households answering "unfavorable" & 0 & 0 & 0 & 0 & 0 \\
\hline \multicolumn{6}{|l|}{ 5. Is land allocation suitable to production? } \\
\hline Number of households answering "suitable" & 140 & 93.3 & 46 & 48 & 46 \\
\hline Number of households answering "unsuitable" & 10 & 6.7 & 4 & 2 & 4 \\
\hline \multicolumn{6}{|l|}{ 6. Do you want to be allocated more land? } \\
\hline Number of households answering "yes" & 15 & 10.0 & 7 & 2 & 6 \\
\hline Number of households answering "no" & 135 & 90.0 & 43 & 48 & 44 \\
\hline \multicolumn{6}{|l|}{ 7. Do you want to return the land? } \\
\hline Number of households answering "yes" & 0 & 0 & 0 & 0 & 0 \\
\hline Number of households answering "no" & 150 & 100 & 50 & 50 & 50 \\
\hline \multicolumn{6}{|l|}{ 8. Do you rent more land for production? } \\
\hline Number of households answering "yes" & 0 & 0 & 0 & 0 & 0 \\
\hline Number of households answering "no" & 150 & 100 & 50 & 50 & 50 \\
\hline \multicolumn{6}{|c|}{ 9. Did you use allocation certificate to get loan? } \\
\hline Number of households answering "get loan" & 37 & 24.7 & 12 & 8 & 17 \\
\hline Number of households answering "not get loan" & 113 & 75.3 & 38 & 42 & 33 \\
\hline \multicolumn{6}{|c|}{ 10. Did you assign the land to others after getting allocation? } \\
\hline Number of households answering "assign" & 0 & 0 & 0 & 0 & 0 \\
\hline Number of households answering "not assign" & 150 & 100 & 50 & 50 & 50 \\
\hline
\end{tabular}

\section{CONCLUSIONS}

The study carried out in Bao Dap, Minh Quan and Au Lau communes of Tran Yen district, Yen Bai province, clearly indicated that farm households were confident of the success of land and forest allocation. It encouraged them to change methods of production, to increase the agricultural land area, to decrease disputes on the land use right and improper use of land, and to develop production from forest. Therefore, it is concluded that the land use effectiveness was increased significantly after land and forest allocation.

\section{REFERENCES}

Nguyen Tat Canh, Do Nguyen Hai, Nguyen The Hung and Kazuhiko Egashira 2002 Agricultural development in the Red River delta, Vietnam - water management, land use, and rice production -. 
J. Fac. Agric., Kyushu Univ., 46(2): 445-464

General References

Government Ordinance No. 64/N\&-CP dated September 27, 1993 Regulations on the allocation of agricultural land to organizations, households and individuals for the stable and long-term use for agricultural purposes (in Vietnamese)

Government Ordinance No. 02/N\&-CP dated January 15, 1994 Regulations on the allocation of forestry land to organizations, households and individuals for the stable and long-term use for forestry purposes (in Vietnamese)

Government Ordinance No. 85/1999/N\&-CP dated August 28, 1999 Revised and enriched regulations on the allocation of agricultural land to organizations, households and individuals for the stable and long-term use for agricultural purposes (in Vietnamese)

Government Ordinance No. 163/1999/N\&-CP dated November 16, 1999 Regulations on the allocation and lease of forestry land to organizations, households and individuals for the stable and long-term use for forestry purposes (in Vietnamese)

Ministry of Agriculture and Rural Development 2002 New Policies for Development of Agriculture, Forestry, Aquatic, Irrigation and Country. Agricultural Publishing House, Hanoi (in Vietnamese)

Yen Bai Statistical Office 2002 Statistical Yearbook. Yen Bai (in Vietnamese) 